\title{
Exposure Analysis of Drinking and Dietary Contaminants in a Selected Population, Padaviya, Anuradhapura
}

\author{
${ }^{1} \mathrm{D}$ M K M Dhanapala, ${ }^{1} \mathrm{H}$ B Asanthi, and ${ }^{2} \mathrm{M} \mathrm{H}$ J P Gunarathne \\ ${ }^{1}$ Department of Limnology, Faculty of Fisheries and Marine Sciences \& Technology, University of Ruhuna, \\ Sri Lanka \\ ${ }^{2}$ Department of Agricultural Engineering \& Soil Science, Faculty of Agriculture, Rajarata University of \\ Sri Lanka
}

\begin{abstract}
This study focused to analyse exposure of selected drinking and dietary contaminants and to assess the health risk for the selected population of Padaviya, Anuradhapura. Thirty families were randomly selected from which fifteen families were with the presence CKDu patients and other fifteen families were with absence of CKDu patients. Questionnaire based social survey was conducted and relevant data were collected for the risk analysis. Water, rice and soil samples were collected on family basis for the quality assessment. Nitrate- $N$, total hardness and fluoride varied within the range of $1.01-23.4 \mathrm{mg} / \mathrm{L}, 40.04-$ $644.58 \mathrm{mg} / \mathrm{L}$ and $0.47-1.92 \mathrm{mg} / \mathrm{L}$ respectively. All physiochemical parameters were significantly different among the wells $(P<0.05)$. Water $p H$, conductivity and TDS in well water were below the Sri Lankan standard for portable water level (SLPWL). However, exceeded SLPWL value of $\mathrm{NO}_{3}-\mathrm{N}(\mathrm{C10}, \mathrm{C14}, \mathrm{C15} \&$ N3), hardness (C12 \& C13) and fluoride (C7, C15 \& N3) were observed in some wells. Both iron and copper concentrations in well water were lower than the provisional maximum tolerable daily intake (PMTDI) of $\mathrm{WHO}$ (Fe: $2 \mathrm{mg} / \mathrm{L}$ and $\mathrm{Cu}: 2 \mathrm{mg} / \mathrm{L}$ ). Dietary iron and copper concentrations in rice were higher than the PMTDI of WHO $(0.5 \mathrm{mg} / \mathrm{kg})$ except for family N7. Copper and Iron varied within the range of $1.55-48.4$ $\mathrm{mg} / \mathrm{kg} d w$ and $467.08-893.61 \mathrm{mg} / \mathrm{kg} d w$ in soil respectively. Probable exposure concentration was higher than probable non-exposure concentration in the selected population. Therefore, Relative Risk for CKDu was greater than 1 for all selected contaminants and it explains that there is a possible risk due to drinking water and eating rice for the selected contaminants. Non-cancer risk values in selected families were higher than the unity of the risk level $\left(1 \times 10^{-6}\right)$ and therefore the contaminants in drinking water and rice in Padaviya area can be considered as risk factors for prevailing chronic kidney disease.
\end{abstract}

KEYWORDS:Exposure, contaminants, drinking, dietary, risk, recommended level 


\section{INTRODUCTION}

The contamination from both natural and anthropogenic sources becomes a major issue which is responsible for serious health problems in world wide. The European Food Safety Authority recommends that women should drink about 1.6 litres of water and men should drink about 2.0 litres of water per day and one person consumes about three or two meals per day. Therefore, water and food consumption is the major exposure route for many human contaminants and degradation of the resource caused by various anthropogenic activities increases the availability of contaminants. Sri Lanka is ranked in the eighth position in the world on the list of countries that use the highest quantity of chemical fertilizer (Mudalige, 2014). The highest usage of fertilizers and agro-chemicals has been reported in North Central Province (NCP), is applied for about 128,000 ha (Weeraratna, 2013). Recent findings show that, some toxic heavy metals including fertilizers and agro chemicals are the major contaminant in Sri Lanka (Jayasumana, 2014; Bandara et al., 2008).

More than $80 \%$ of the rural drinking water supply needs are met from groundwater by means of dug wells and tube wells (Panabokke \& Perera, 2005). High Fluoride levels (above $1.5 \mathrm{mg} / \mathrm{L}$ ) in well water in dry zone had been observed as far back as 1976 . Subsequent studies have shown that $40 \%$ of wells in NCP were rich in Fluoride and a number of 456 deep tube wells in Anuradhapura district have also been found with Fluoride ranging from 0.78 to $2.68 \mathrm{mg} / \mathrm{L}$ (Lasanntha et al., 2008). The same study reported that $34 \%$ of the wells exceeded the maximum desirable level of $100 \mathrm{mg} / \mathrm{L}$ of calcium in drinking water and also $8 \%$ of the wells exceeded the maximum permissible level of $240 \mathrm{mg} / \mathrm{L}$ in Anuradhapura District. Electrical conductivity in Anuradhapura district reported as $350 \mu \mathrm{S} / \mathrm{cm}$ indicating the abundance of electrolytes in water (Dissanayake, 2005).

Nowadays, chemical contaminants are a major concern for food safety because of the increased role of man-made chemicals due to our modern lifestyles. Rice is the main diet of Sri Lankans in all over the country and rice and other several popular food items have been contaminated from heavy metals such as cadmium (Bandara et al., 2008). The heavy metal contamination like cadmium was observed in rice, Nelumbonucifera (Lotus) rhizomes, cow's milk and in Tilapia (Oreochromisniloticus) (Bandara et al., 2008). The overuse and misuse of agrochemicals would be contributed to heavy metal contamination $(\mathrm{Cd}, \mathrm{Cr}, \mathrm{Ni}, \mathrm{Pb}, \mathrm{As}$ etc.) and for both acute and chronic renal failure (Bandara et al., 2010).

Therefore, this study was aimed to identify the major contaminants in drinking water and in selected food types in Padaviya area and to follow the risk assessment model in order to assess the exposure levels of above identified contaminants.

\section{MATERIALS AND METHODS}

\section{Study Area}

The study area was decided according to the data taken from Office of the Provincial Director of Health Services, North Central Province, Anuradhapura regarding prevalence of CKDu (Fig 1). Padaviya is $93 \mathrm{~km}$ away from Anuradhapura and it receives $1450 \mathrm{~mm}$ mean annual rainfall and available from October to March. A questionnaire based social survey and laboratory analyses were carried out to collect data for human health risk assessment. Thirty families were selected representing fifteen families with the 
presence of $\mathrm{CKDu}$ patients and other fifteen families with the absence of CKDu patients.

\section{Collection of Samples}

Paranagama (2013) has reported that sources of drinking water of CKDu patients are dug wells $(92 \%)$ and tube wells $(8 \%)$. Therefore, water samples were collected from the water sources such as dug wells, tube wells, etc. belongs to the selected families. On site measurement of $\mathrm{pH}$, conductivity, Total Dissolved Solid (TDS), salinity, Dissolved Oxygen (DO), temperature were taken by Multi - Parameter Meter (HACH sens ION 156). The filtered water samples were stored with ice in a heat insulated box for facilitating transportation. Rice samples were collected from the selected families while soil samples were collected from their own paddy fields.

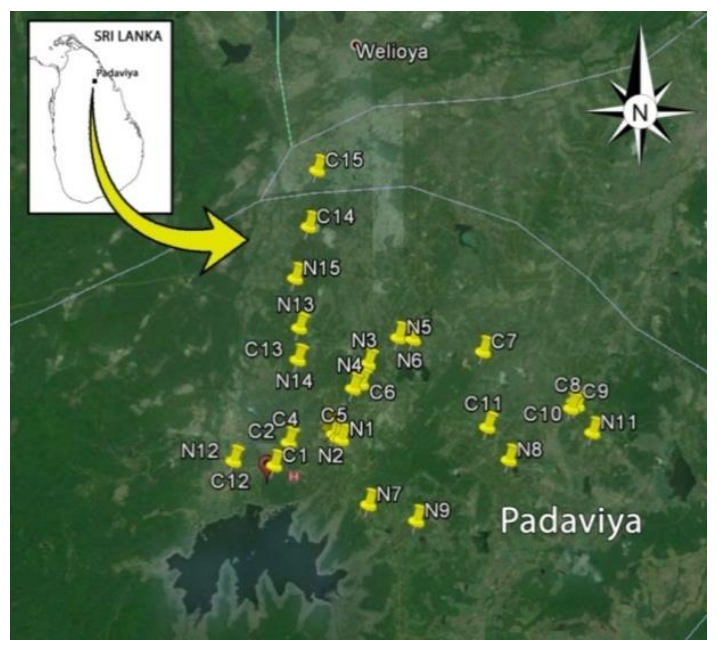

Figure 1. GPS locations of sampling in Padaviya area; Source :(Earth.google.com, 2014)

\section{Analysis of chemical parameters}

The filtered water samples were analyzed for Nitrate-N according to the Sodium Salicylate method, water soluble salts of phosphoric acid were measured by automated ascorbic acid reduction method (Rand et al., 1975, p.481-482) and organic phosphorous content of each water sample were measured by persulphate digestion method and the automated ascorbic acid reduction method (Rand et al., 1975, p. 481-482). Fluoride concentration of each filtered water sample was measured directly by HATCH-DR 4000U Spectrophotometer at a wave length of $580 \mathrm{~nm}$ using SPADNS solution (Rand et al., 1975, p.393-394). Also, the water samples were analysed for total hardness by EDTA titration method.

\section{Analysis of heavy metals}

Filtered water sample were acidified with $10 \%$ Conc. Nitric acid (Analar grade). Collected rice samples were thoroughly washed several times with deionized water and the sample was dried at $105^{\circ} \mathrm{C}$ in an oven until obtained a constant weight. Dried samples were ground to fine powder using mortar and pestle and fine powder was sieved using 250 $\mu \mathrm{m}$ sieve. Then, $5 \mathrm{~mL}$ of concentrated $\mathrm{HNO}_{3}$ $(65 \%)$ and $2.5 \mathrm{~mL}$ of $\mathrm{H}_{2} \mathrm{O}_{2}(30 \%)$ were added to each $0.5 \mathrm{~g}$ of sieved rice samples and the solution was heated on Kjeldhal Heating Digester under fume hood at $80^{\circ} \mathrm{C}$, for $2-3 \mathrm{~h}$, till the clear transparent solutions were obtained. The final solutions were filtered through Whatman No. 41 filter paper (Jalbani et al., 2014). All soil samples were air dried on polypropylene sheets at room temperature for several days until they were deprived of moisture. Then the soil samples were well ground using porcelain mortar and pestle and were sieved through a $250 \mu \mathrm{m}$ mesh sized sieve. The pre-digestion step was done at room temperature for $24 \mathrm{~h}$ with $10 \mathrm{~mL}$ of a (3:1) mixture of $12 \mathrm{M} \mathrm{HCl}$ and $17 \mathrm{M} \mathrm{HNO}_{3}$. The suspension was digested on GK 06 Kjeldhal Heating digester under fume hood at $130^{\circ} \mathrm{C}$ for $15 \mathrm{~min}$. The obtained suspension was cooled at room temperature and filtered through Whatman No. 41 filter paper (PeñaIcart et al., 2011). 
A series of standard metal solutions were prepared for $\mathrm{Cu}$ using the stock solutions of $1,000 \quad \mathrm{mg} / \mathrm{L} \quad$ (BDH chemicals). Concentrations of $\mathrm{Cu}$ were measured using Atomic Absorbance Spectrophotometer (SpectrAA 220 AAS). Iron concentration of rice, soil and water samples were measured according to the Thiocyanate colorimetric method (University of Canterbury, 2011).

\section{Human Health Risk Assessment}

The data, which had taken from questionnaire based social survey, were prepared to be used for the risk assessment.

Exposure Analysis of water and dietary intake

$$
I=\frac{C \times I G R \times E F \times E D \times C F}{B W \times A T \times 365}
$$

Where,

$$
\begin{aligned}
& I= \begin{array}{l}
\text { Intake of chemical } \\
(\mathrm{mg} / \mathrm{kg} / \text { day })
\end{array} \\
& C= \begin{array}{l}
\text { Average chemical } \\
\text { concentration in food } \\
(\mathrm{mg} / \mathrm{kg})
\end{array} \\
& I G R= \text { Ingestion rate (mg/day) } \\
& E F= \begin{array}{l}
\text { Exposure frequency } \\
\text { (days/year) }
\end{array} \\
& E D= \text { Exposure duration (years) } \\
& C F= \text { Conversion factor (If units } \\
& \text { in above parameters don't } \\
& \text { match) } \\
& B W= \text { Average Body weight }(\mathrm{kg}) \\
& A T= \begin{array}{l}
\text { Average exposure time } \\
(\text { years })
\end{array} \\
& C D I=\frac{C \times C R \times E F \times E D \times C F}{B W \times A T}
\end{aligned}
$$

Where,

$$
\begin{aligned}
C D I= & \text { Chronic daily intake of } \\
& \text { water }(\mathrm{mg} / \mathrm{kg} / \text { day }) \\
C= & \text { Chemical concentration in } \\
& \text { water }(\mathrm{mg} / \mathrm{L}) \\
C R= & \text { Consumption rate }(\mathrm{L} / \text { day })
\end{aligned}
$$

$$
\begin{aligned}
E F= & \text { Exposure frequency (days/year) } \\
E D= & \text { Exposure duration (years) } \\
C F= & \text { Conversion factor (If units in above } \\
B W= & \text { Avarameters don't match) } \\
A T= & \text { Average exposure time (days) } \\
& \text { Source }:(\text { enHEALTH, 2012) }
\end{aligned}
$$

\section{Determination of Non_Cancer Risk}

Where,

$$
\text { Risk }=R F D \times \text { Exposure }
$$

$$
R F D=\text { Reference Dose }
$$

Determination of Relative Risk (RR)

$$
R R=\frac{P E C}{P N E C}
$$

Where,

$P E C=$ Probable Exposure Concentration$$
P N E C=\text { Probable Non }
$$$$
\text { Exposure }
$$

Concentration

\section{Statistical analysis}

Oneway ANOVA was carried out to determine the difference of the water quality parameters among the selected wells. The multiple comparison of the water quality parameters was performed using Tukey HSD test (SPSS, Version 16.0).

\section{RESULTS AND DISCUSSION}

The physical parameters of $\mathrm{pH}$, conductivity and Total dissolved solid (TDS), did not exceed Sri Lankan standard for portable water level/SLPWL (SLS 614, 1983) and there was a significant difference among the above mentioned parameters in 30 wells $(\mathrm{P}<$ 0.05 ). Water $\mathrm{pH}$ and electrical conductivity 
(EC) varied within the range of $6.86-7.95$ and $16.25-755 \mu \mathrm{s} / \mathrm{cm}$ respectively (Table 1 ).

Table 1. Physical parameters of well water

\begin{tabular}{|c|c|c|}
\hline & Value & $\begin{array}{l}\text { Significantly different } \\
\text { wells }\end{array}$ \\
\hline \multicolumn{3}{|r|}{ ( } \\
\hline Mean \pm SD & $7.37 \pm 0.31$ & \multirow[t]{2}{*}{$\mathrm{C} 1, \mathrm{C} 6, \mathrm{C} 7 \& \mathrm{~N} 10$} \\
\hline Range & $6.86-7.95$ & \\
\hline \multicolumn{3}{|l|}{$\begin{array}{l}\text { Electrical } \\
\text { Conductivity } \\
(\mu \mathrm{s} / \mathrm{cm})\end{array}$} \\
\hline Mean \pm SD & $\begin{array}{c}477.23 \pm \\
211.78\end{array}$ & \multirow[t]{2}{*}{$\begin{array}{l}\mathrm{C} 1, \mathrm{C} 8, \mathrm{C} 9, \mathrm{C} 10, \mathrm{C} 13, \mathrm{~N} 2 \\
\& \mathrm{~N} 10\end{array}$} \\
\hline Range & $\begin{array}{c}16.25- \\
755.0 \\
\end{array}$ & \\
\hline \multicolumn{3}{|l|}{ TDS (mg/L) } \\
\hline Mean \pm SD & $\begin{array}{c}236.85 \pm \\
106.4\end{array}$ & \multirow[t]{2}{*}{$\begin{array}{l}\text { C1, C4, C8,C9, N2, N5, } \\
\text { N6,N8, N9 \& N10 }\end{array}$} \\
\hline Range & $6.3-378$ & \\
\hline \multicolumn{3}{|l|}{$\begin{array}{l}\text { Temperature } \\
\left({ }^{\circ} \mathrm{C}\right)\end{array}$} \\
\hline Mean \pm SD & $29.5 \pm 2.16$ & \multirow{2}{*}{ - } \\
\hline Range & $27.4-36.1$ & \\
\hline
\end{tabular}

(Non_Case)

Jayawardana et al. (2010) has reported that changing of $\mathrm{pH}$ values from weak acidic to weak basic (4.0 to 8.2 with the average of 7.2) with very low EC values $(2.40 \mathrm{mS} / \mathrm{m})$ indicated that dissolved ionic species are very low in the water. They have also explained that, in dry zone, fluoride values increase in the condition with slightly alkaline $\mathrm{pH}(7.5-$ $8.2)$ and relatively low EC (1.0-2.5 $\mathrm{mS} / \mathrm{m})$ (Jayawardana et al., 2010). Mechenich \& Andrews (2004) have reported, that the much greater hardness may indicate the presence of contaminants which may occur naturally or be influenced by human activity. In the current study, TDS values of most of the wells were much greater than two times of the hardness (Ex. Well no. C3).

Many researchers said that water hardness, high level of fluoride and contamination of heavy metals can effect on human health (Bandara et al., 2010; Bandara et al., 2008; Dissanayake, 2005). In the present study total hardness and fluoride varied within the range as $40.04-644.58 \mathrm{mg} / \mathrm{L}$ and $0.47-1.92 \mathrm{mg} / \mathrm{L}$ respectively. The concentration of nitrate- $\mathrm{N}$ varied from 1.01 to $23.4 \mathrm{mg} / \mathrm{L}$ among the 30 wells. Paranagama (2013) has observed nitrate-N varied from $0.3 \times 10^{-6}$ to $5.82 \times 10^{-6}$ $\mathrm{mg} / \mathrm{L}$ in Padaviya. All chemical parameters were significantly different among the wells $(\mathrm{P}<0.05)$. Some parameters as $\mathrm{NO}_{3}-\mathrm{N}(\mathrm{C} 10$, $\mathrm{C} 14, \mathrm{C} 15 \& \mathrm{~N} 3)$, hardness (C12 \& C13) and fluoride (C7, C15 \& N3) concentrations exceeded the SLPWL (SLS 614, 1983) (Table $2)$. Both iron and copper concentrations in well water were lower than the provisional maximum tolerable daily intake (PMTDI) of WHO (Fe: $2 \mathrm{mg} / \mathrm{L}$ and $\mathrm{Cu}: 2 \mathrm{mg} / \mathrm{L}$ ). Dietary iron concentrations in rice were higher than the PMTDI of WHO $(0.8 \mathrm{mg} / \mathrm{kg})$ and copper concentrations in rice were higher than the PMTDI of WHO $(0.5 \mathrm{mg} / \mathrm{kg})$ except in the sample taken from family N7. Copper and Iron varied within range of $1.55-48.4$ $\mathrm{mg} / \mathrm{kgdw}$ and 467.08 - $893.61 \mathrm{mg} / \mathrm{kgdw}$ respectively in the soil.

It was noted that the wells located closer to the paddy fields have exceeded the nitrate concentration than SLPWL (SLS 614, 1983). Gunatilake and Iwao (2010) also have reported that, during the period of fertilizer application to paddy fields the drinking water wells located nearby paddy fields are more vulnerable to nitrate contamination.

Organic phosphorous in well water varied from 0.1 to $0.39 \mathrm{mg} / \mathrm{L}$. Paranagama (2013) has reported that phosphate varied range of $61.1 \times 10^{-6}-80.25 \times 10^{-6} \mathrm{mg} / \mathrm{L}$ in well water. Generally, organic matter decomposition is lower in well water than in surface water and microbial decomposition is the main way of entering orthophosphate into the well water Young et al (2010). Therefore, low concentration of orthophosphate was observed in the well water is said that phosphate concentrations in wells found in different soil formations show distinctive variations. 
The fluoride concentration in groundwater of dry zone, Sri Lanka lies in a range of 0.1 to $4.7 \mathrm{mg} / \mathrm{L}$ (Johnson et al., 2012). Fluoride may leach into groundwater due to weathering of fluoride-rich minerals in the basement rocks and climate and geological formation of dry zone are the most preferred factors for elevated fluoride level in water (Jayawardana et al., 2010).Furthermore, above study mentioned that the dry zone aquifers are well known for higher fluoride concentrations and fluoride-related endemic diseases and chronic renal failures. As a major component in acidic soils, iron hydroxides serve as an important sink for fluoride in soil resulting into the enhancement of fluoride concentration in water under acidic conditions (Chandrajith et al., 2012). In dry zone, soil consists with reddish-brown earth which predominates by iron rich biotite gneisses of the Khondalite series (Kalpage et al., 1963). In the current study, iron content in soil varied from $467.08-893.61 \mathrm{mg} / \mathrm{kg} \mathrm{dw}$. The soil Iron content of each sampling site was poorly correlated with fluoride content of relevant water samples. Jayawardana et al. (2010) has shown in oxidized environment in the field of $\mathrm{Fe}_{2} \mathrm{O}_{3}$ and it should be the result for poor relationship of iron with fluoride.

Total hardness ranged between 40.04 $644.58 \mathrm{mg} / \mathrm{L}$ and the water hardness in most of selected wells was lower than the recommended level of $600 \mathrm{mg} / \mathrm{L}$ in Sri Lanka except two wells (C12 \& C13). The average groundwater hardness was observed in Padaviya by Fonseka et al. (2012) as $466 \pm$ $34 \mathrm{mg} / \mathrm{L}$. However, it is important to consider total hardness as an important public health issue (Emmanuel et al., 2013). Similarly, Jayasumana et al. (2014) has reported a correlation between the places with high ground water hardness and the geographical distribution of the $\mathrm{CKDu}$ in Sri Lanka andthese areas contain $\mathrm{Ca}, \mathrm{Mg}, \mathrm{Fe}$ and $\mathrm{Sr}$ ions in water also. Iron content of drinking water varied from 0.0011 to $0.0084 \mathrm{mg} / \mathrm{L}$ in the selected wells and those values did not exceed the recommended level of $0.3 \mathrm{mg} / \mathrm{L}$. Paranagama (2013) revealed somewhat lower values than in the present study ranged as 0.00014 - $0.00046 \mathrm{mg} / \mathrm{L}$ in Padaviya area. Jayawardana et al.(2010) has reported low values of iron in water samples because iron is generally stable in acidic $\mathrm{pH}$.

Table 2. Chemical parameters of well water

\begin{tabular}{|c|c|c|}
\hline & Value & $\begin{array}{l}\text { Significantly } \\
\text { different wells }\end{array}$ \\
\hline \multicolumn{3}{|l|}{$\begin{array}{l}\text { Nitrate-N } \\
(\mathrm{mg} / \mathrm{L})\end{array}$} \\
\hline Mean \pm SD & $3.51 \pm 5.32$ & \multirow[t]{2}{*}{$\begin{array}{l}\text { C2, C10, C13, C14, } \\
\text { C15 \& N3 }\end{array}$} \\
\hline Range & $1.01-23.4$ & \\
\hline \multicolumn{3}{|c|}{ Total Hardness (mg/L) } \\
\hline Mean \pm SD & $\begin{array}{c}161.48 \pm \\
152.05\end{array}$ & \multirow{2}{*}{$\begin{array}{l}\text { Most wells except C2, } \\
\text { C4, C5, C6, C7, C11, } \\
\text { N1, N2, N4, N5 \& N7 }\end{array}$} \\
\hline Range & $\begin{array}{l}40.04- \\
644.58\end{array}$ & \\
\hline \multicolumn{3}{|l|}{$\begin{array}{l}\text { Fluoride } \\
\text { (mg/L) }\end{array}$} \\
\hline Mean \pm SD & $0.73 \pm 0.37$ & \multirow[t]{2}{*}{$\begin{array}{l}\text { C7, C15, N3, N8, N9 } \\
\& \text { N15 }\end{array}$} \\
\hline Range & $0.47-1.92$ & \\
\hline \multicolumn{3}{|c|}{ Organic phosphorous } \\
\hline Mean \pm SD & $0.08 \pm 0.11$ & \multirow[t]{2}{*}{ C1, C3, N5 \& N10 } \\
\hline Range & $0.1-0.39$ & \\
\hline
\end{tabular}

$\mathrm{C}: \mathrm{CKD}$ patients present in the family (Case)

$\mathrm{N}$ : No one present with $\mathrm{CKD}$ in the family (Non_Case)

Copper and iron in rice collected from selected families were observed as Fe; 2.29 $35.21 \mathrm{mg} / \mathrm{kg}$ and $\mathrm{Cu} ; 0.3-33 \mathrm{mg} / \mathrm{kg}$ ). In rice samples, $\mathrm{Cu}$ and iron concentrations were higher than the provisional maximum tolerable daily intake (PMTDI) of WHO (Fe; $0.5 \mathrm{mg} / \mathrm{kg}$ and $\mathrm{Cu} ; 0.8 \mathrm{mg} / \mathrm{kg}$ ) except only from family (N7).

Copper and iron content of soil varied from 1.55 to $48.4 \mathrm{mg} / \mathrm{kg}(\mathrm{dw})$ and from 467.08 to 
$893.61 \mathrm{mg} / \mathrm{kg}$ (dw) respectively. The iron rich soil in dry zone has an ability to retain arsenic ions and can be accumulated those (Jayasumana et al., 2014). Recently, arsenic plays main role of chronic renal failure in dry zone of Sri Lanka (Paranagama, 2013). It implies that arsenic is not present naturally in soils nevertheless has been introduced from the surface, most probably due to anthropogenic activities. Today, most of the researchers have been investigated that agrochemicals and fertilizers are the major source of arsenic (Berg et al., 2001).

Jayasumana et al. (2014) has reported that a chemical which contain in "round up" is a major causative agent for chronic kidney disease and the chemical is Glycophosate. Hard water in dry zone with high concentration of calcium, magnisium and strontium are combined with glycophosate and easily forms complexes. Ferric ions also play a significant role in the process of adsorption of glyphosate in soil. As a result of current study, high value of total hardness and iron content in soil are correlated with the case group of $\mathrm{CKDu}$.

Collected information from the social survey was important for exposure analysis of each drinking and dietary contaminants. Total exposure in case group (PEC) of all contaminants was higher than total contaminants in non_case group (PNEC) (Figure 2). It implies intake amount of relevant contaminant per day in the case group was high.

(a)

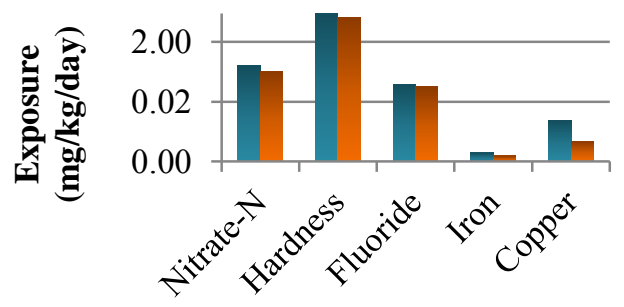

Contaminant (b)

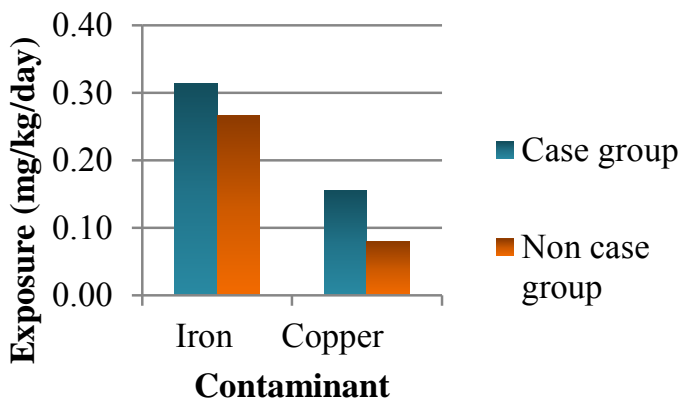

Figure 2.Total Exposure of selected contaminants in (a) water (b) rice

The relative risk of each drinking and dietary contaminants were greater than 1 (one) according to PEC and PNEC of selected families (Table 3). It explains that, there is a relative risk from each contaminant in the selected population.

Table 3. Relative Risk (RR) of selected contaminants

\begin{tabular}{|l|c|c|}
\hline Contaminants & $\begin{array}{c}\text { RR of drinking } \\
\text { contaminants }\end{array}$ & $\begin{array}{c}\text { RR of dietary } \\
\text { contaminants }\end{array}$ \\
\hline $\mathrm{NO}_{3}^{-} \mathrm{N}$ & 1.58 & - \\
\hline $\begin{array}{c}\text { Hardness } \\
+2 \\
(\mathrm{Ca} \& \mathrm{Mg})\end{array}$ & 1.40 & - \\
\hline Fluoride & 1.20 & - \\
\hline Iron & 1.26 & 1.18 \\
\hline Copper & 5.06 & 1.95 \\
\hline
\end{tabular}

(Won_cancer risk of each contaminant in selected families was higher than the unity of the criteria $\left(1 \times 10^{-6}\right)$ (Table 4$)$. It reveals, in a population of one million people, additional person or persons would be expected to develop risk from considered contaminants in the study. When comparing the risk values separately for groups considering highest and lowest concentrations male group was the 
most vulnerable group for drinking (Table 4) and dietary contamination than other two groups (Table 5).

Table 4. Non-cancer risk for selected drinking contaminants

\begin{tabular}{|c|c|c|c|c|}
\hline \multirow{2}{*}{ Contaminants } & \multirow{2}{*}{ Code } & \multicolumn{3}{|c|}{ Drinking Risk } \\
\hline & & Male & Female & Children \\
\hline \multicolumn{5}{|l|}{$\mathrm{NO}_{3}{ }^{-}-\mathrm{N}$} \\
\hline $\mathrm{HC}$ & C14 & 1.1724 & 0.8245 & 0.0000 \\
\hline $\mathrm{LC}$ & C7 & 0.0844 & 0.0824 & 0.0000 \\
\hline \multicolumn{5}{|l|}{ Hardness } \\
\hline $\mathrm{HC}$ & C12 & 76.7066 & 85.6754 & 53.4081 \\
\hline $\mathrm{LC}$ & C3 & 3.1797 & 3.4396 & 7.2565 \\
\hline \multicolumn{5}{|l|}{ Fluoride } \\
\hline $\mathrm{HC}$ & $\mathrm{C} 7$ & 0.0055 & 0.0053 & 0.0000 \\
\hline $\mathrm{LC}$ & N8 & 0.0007 & 0.0009 & 0.0000 \\
\hline \multicolumn{5}{|l|}{ Iron } \\
\hline $\mathrm{HC}$ & $\mathrm{C} 7$ & $3.5 \times 10^{-6}$ & $3.4 \times 10^{-6}$ & 0.0000 \\
\hline $\mathrm{LC}$ & $\mathrm{C} 2$ & $1.1 \times 10^{-6}$ & $1.1 \times 10^{-6}$ & 0.0000 \\
\hline \multicolumn{5}{|l|}{ Copper } \\
\hline $\mathrm{HC}$ & $\mathrm{C} 7$ & $1.9 \times 10^{-4}$ & $1.8 \times 10^{-4}$ & 0.0000 \\
\hline $\mathrm{LC}$ & N12 & 0.0000 & 0.0000 & $3.6 \times 10^{-5}$ \\
\hline
\end{tabular}

HC: Highest concentration among 30 families

LC: Lowest concentration among 30 families

Table 5. Non-cancer risk for selected dietary contaminants

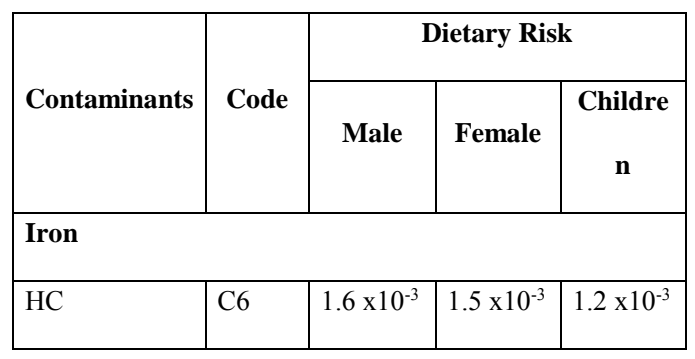

\begin{tabular}{|l|l|l|l|l|}
\hline LC & N6 & $5.2 \times 10^{-4}$ & $4.1 \times 10^{-4}$ & $9.3 \times 10^{-4}$ \\
\hline Copper \\
\hline HC & C9 & $3.6 \times 10^{-4}$ & $5.1 \times 10^{-4}$ & $8.8 \times 10^{-4}$ \\
\hline LC & N9 & $6.7 \times 10^{-5}$ & $6.5 \times 10^{-5}$ & 0.0000 \\
\end{tabular}

HC: Highest concentration among 30 families

LC: Lowest concentration among 30 families

\section{Summary of social survey}

Padaviya is a rural village in Sri Lanka and the lives of people are slowly flowing by fulfilling their requirements from the village. Main occupations are paddy cultivation, chena cultivation and cultivation of seasonal crops. About $90 \%$ of people use ground water from dug wells, tube wells, springs, etc. Recently, some filtering water facilities have been settled everywhere by the government and private sector. However, the villagers have to pay for their own drinking water. The majority of people are suffering from CKDu and it is becoming an uncertainty health problem. Most of the farmers do not imitate safety methods in applying agrochemicals and also some habits such as; chewing beetle and taking alcohol were observed.

\section{CONCLUSION}

Since all physiochemical parameters were significantly different among the wells it should be paid individual attention for the wells on their quality of the water. However, $\mathrm{pH}$, conductivity and TDS in well water were below the Sri Lankan standard for portable water level (SLPWL). The exceeded values than the SLPWL was observed for $\mathrm{NO}_{3}-\mathrm{N}$, hardness and fluoride in some wells. Both iron and copper concentrations in well water were lower than the provisional maximum tolerable daily intake (PMTDI) of WHO.

Total exposure in case group (PEC) of all contaminants was higher than total 
contaminants in non_case group (PNEC) explains that there is a relative risk of each drinking and dietary contaminants and it should be assessed further.

\section{REFERENCES}

BANDARA JMRS, SENEVIRATHNA DM AN, DASANAYAKE DMRSB \& HERATH V. Chronic renal failure among farm families in cascade irrigation systems in Sri Lanka associated with elevated dietary cadmium levels in rice and freshwater fish (Tilapia). Environmental Geochemistry and Health. 2008; 30(5): 465-478.

BANDARA JMRS, WIJEWARDENA HVP, LIYANAGE J, UPUL MA \& BANDARA JMUA. Chronic renal failure in Sri Lanka caused by elevated dietary cadmium: Trojan horse of the green revolution. Toxicology Letters. 2010; 198: 33-39.

BERG M, TRAN HC, NGUYENTC, PHAM HV, SCHERTENLEIB R. \& GIGER W. Arsenic Contamination of Groundwater and Drinking Water in Vietnam: A Human Health Threat. Environmental Science \& Technology. 2001; 35(31), 2621-2626.

CHANDRAJITH R, PADMASIRI JP, DISSANAYAKE CB \& PREMATILAKA KM. Spatial distribution of fluoride in groundwater of Sri Lanka. Journal of the National Science Foundation of Sri Lanka. 2012; 40(4), 303-309.

DISSANAYAKE CB. Water Quality In The Dry Zone Of Sri Lanka - Some Interesting Health Aspects. J.Natn.Sci.Foundation Sri Lanka. 2005; III(33): 161-168.

EARTH.GOOGLE.COM, Google Earth. Available from: https://earth. google.com. 2014. (Accessed 11 Dec. 2014).
EMMANUEL E, SIMON Y \& JOSEP O. Characterization of hardness in the groundwater of port-au-prince. An overview on the health significance of magnesium in the drinking water. Aqua-LAC,2013. 5(2), 35 -43 .

ENHEALTH. Environmental Health risk assessment. Canberra: Department of health and ageing. 2012.

FONSEKA S, JAYASUMANA C, JAYALATH K, AMARASINGHE M, SENANAYAKE $\mathrm{K}$, WIJEWARDHANE C, SAMARASINGHE D, DAHANAYAKE K, MAHAMITHAWA P \& PARANAGAMA P. Arsenic and hardness in ground water from chronic kidney disease of unknown etiology $(\mathrm{CKDu})$ prevalent areas and non-CKDu prevalent areas in sri lanka.2012. In Ileperuma, O.A. et al., eds. International Symposium on Water Quality and Human Health: Challenges Ahead. Peradeniya, 2012.

GUNATILAKE SK \& IWAO Y. A Comparison of Nitrate Distribution in Shallow Groundwater of Two Agricultural Areas in Sri Lanka and in Japan. Sabaramuwa University Journal. 2010; 9(1), 81-95.

JALBANI N, AFTAB AK, BHUTTO S, AHMED F \& MAHROZE AK. Evaluation of toxic elements in rice (Oryza sativa) commercially available in Pakistan; multivariate study. International Food Research Journal. 2014; 21(1): 255-261.

JAYASUMANA C, GUNATILAKE S \& SENANAYAKE P. Glyphosate, Hard Water and Nephrotoxic Metals: Are They the Culprits Behind the Epidemic of Chronic Kidney Disease of Unknown Etiology in Sri Lanka? International Journal of Environmental Research and Public Health 2014; 11: 2125-2147.

JAYAWARDANA DT, PITAWALA HMTGA \& ISHIGA H. Groundwater Quality 
in Different Climatic Zones of Sri Lanka: Focus on the Occurrence of Fluoride. International Journal of Environmental Science and Development. 2010; 1(3), 244250.

JOHNSON S, MISRA SS, SAHU R \& SAXENA P. Environmental contamination and its association with Chronic Kidney Disease of Unknown Etiology in North Central Region of Sri Lanka. pdf. New Delhi: Centre For Science And Environment.2012.

KALPAGE FSCP, MITCHELL BD \& MITCHELL WA.The Mineralogy Of Some Ceylon Soils. The Macaulay Institute for Soil Research.1963.

LASANNTHA PAPGR, GONAWALA JML. \& WIJEKOON D. Groundwater Quality in Anuradhapura District with Special Reference to Fluoride. Groundwater in Sri Lanka- A Most precious but Highly Threatened Resource. 2008; 1: 48-64.

MECHENICH C. \& ANDREWS E.Interpreting Drinking Water Test Results. pdf. Madison: Cooperative Extension Publishing University of Wisconsin.2004.

MUDALIGE D. Sri Lanka among eight countries with highest use of agrochemicals. Daily News. 2014. Available from: $\quad$ http://http. Ilwww.dailynews.lk/ (Accessed 12 Mar. 2014).

PANABOKKE CR \& PERERA APGRL. Groundwater Resources Of Sri Lanka. Report. Colombo 7: Water Resources Board. 2005.

PARANAGAMA PA. Potential link between ground water hardness, arsenic content and prevalence of CKDu. 2013; Available from: http://www.nas-srilanka.org. http://www.nassrilanka.org (Accessed 23 October 2014).

PEÑA-ICART M, TAGLEMEV, HERNÁNDEZCA, HERNÁNDEZ JR, BEHAR $M$ \& ALFONSO MSP.. Comparative Study of Digestion Methods EPA 3050B (HNO3-H2O2-HCl) and ISO 11466.3 (aqua regia) for $\mathrm{Cu}, \mathrm{Ni}$ and $\mathrm{Pb}$ Contamination Assessment in Marine Sediments. Marine Environmental Research. 2011;72(2): 1-88.

RAND MC, GREENBERG AE, TARAS MJ \& FRANSON MA. EDS.Standard Methodsfor the Examination of water and wastewater. 4th ed. Washington: American Public Health Association. 1975.

SLS 614. Specification for portable water physical and chemical requirement. National Water Supply \& Drainage Board. 1983.

UNIVERSITY OF CANTERBURY. Determination of iron by thiocyanate colorimetry. 2011; University of Canterbury Available from: http://www.outreach. canterbury.ac.nz. http://www.outreach. canterbury.ac.nz (Accessed 25 September 2014).

WEERARATNA C. Fertilizer Use in Sri Lanka with special reference to CKDu. 2013.

WORLD HEALTH ORGANIZATION. Total dissolved solids in Drinking-water. Guidelines for Drinking-water Quality. Geneva: World Health Organization World Health Organization. 1996.

YOUNG SM, PITAWALA \& GUNATILAK $J$. Fate of phosphate and nitrate in waters of an intensive agricultural area in the dry zone of Sri Lanka. Paddy Water Environment. $2010 ; 8,71-79$. 